JUSTYNA TRACZ

Department of Geobotany, Maria Curie-Skłodowska University, Akademicka 19, 20-033 Lublin, Poland, justyna.tracz@gmail.com

\title{
CHANGES OF DENTARIO GLANDULEOSAE-FAGETUM FOREST STAND IN ROZTOCZE NATIONAL PARK, SOUTH EASTERN POLAND FROM 1946 TO 2001
}

\begin{abstract}
Roztocze Nation Park (RNP) is located in the central part of Roztocze, a hilly region in south-eastern Poland. The most important type of forest community in RNP is Dentario glandulosae-Fagetum. Potential and real vegetation, as well as forest stand maps were used to analyze changes of the age and species structure of beechwood stand from 1946 to 2001. Beechwoods were dominated by two species: fir and beech. During the last 50 years their proportion has entirely changed and the share of oldest groups of stand (over 120 years old) has increased significantly.
\end{abstract}

Key words: beechwood, Roztocze, forest stand changes

\section{INTRODUCTION}

\subsection{General information}

Roztocze is a group of hills in south-east Poland, which ranges from Kraśnik to Lwów (Ukraine). In the north Roztocze borders with the Lublin Upland, and in the south with the Sandomierz Dale. Its highest elevation is $391.5 \mathrm{~m}$ above sea level. This region differs from the neighbouring areas. Roztocze is located on the Vistula River and the Bug River watershed and is under the influence of continental climate but due to its altitude annual sum of atmospheric precipitation in the region is higher than the average for Poland. Geological structure of Roztocze is also unique as the region is located in the Teisseyre-Tornquist Zone - the line of contact of East 
European craton and paleozoic structures of Western Europe. This region is also interesting due to its geobotanical features. Natural ranges of several tree species have their edges at the territory of Roztocze. These are European Beech (Fagus sylvatica), Silver Fir (Abies alba), Norway Spruce (Picea abies), Large-leaved Lime (Tilia platyphyllos) and Sycamore Maple (Acer pseudoplatanus). In spite of the borderline range, these species are dynamic and vital in Roztocze region. What is more, two montane associations: Dentario glandulosae-Fagetum and Abietetum polonicum are present in Roztocze (BURACZYŃSKI 2002; WILGAT 2004)

Roztocze National Park (RNP) is situated in the Central Roztocze. This national nark with area of 8483 ha is predominantly woody and as much as $95.5 \%$ of its area is covered with forests. All types of vegetation are well-preserved. Almost $10 \%$ of RNP is under the protection of nature reserves. RNP has been established in 1974 and covered an area of 1064.38 ha which was under the surveillance of Kosobudy and Zwierzyniec Forest Districts. The history of nature conservation at the territory of RNP has begun in 1936 when Bukowa Góra reserve has been established (LIS 1979; BRZYSKI 1983; WILGAT 2004).

\subsection{Characteristic of beechwoods in Roztocze National Park}

Dentario glandulosae-Fagetum is the most important association in Roztocze National Park. It occupies $26 \%$ of the Park area and it is one of the montane associations characteristic for the Roztocze region. Natural beechwoods of Roztocze have been changed by an inappropriate forest management - the Scots Pine (Pinus sylvestris) has been planted on Dentario glandulosae-Fagetum habitats and some parts of stand have been cut completely. Nowadays this type of forest occupies 55\% of its natural habitat, the rest of the area is taken up by the substitute association from Querco-Fagetea class (IzDEBSKI et al. 1992; WILGAT 2004, Fig. 1, Table 1).

Usually Dentario glandulosae-Fagetum is thorny and its canopy is multilayer. The area of a tree crown surface is $70-90 \%$. The canopy of most stands is two-layer. Upper-canopy layer is built by European Beech (Fagus sylvatica), alone, the mixture of European Beech and Silver Fir (Abies alba), or rarely exclusively by Sliver Fir. Single specimen of European Hornbeam (Carpinus betulus), Small- 
leaved Lime (Tilia cordata), Norway Maple (Acer platanoides), Sycamore Maple (Acer pseudoplatanus), and Wych Elm (Ulmus glabra) may also be found in this layer. Lower-canopy layer is dominated by European Beech and European Hornbeam., in some parts with significant share of Silver Fir. European Beech individuals are not robust except the most fertile habitat but Silver Fir specimens are very robust. There are specimens 40 meter high and of 3 meter circumference of beech and fir in the Park.

Understory layer surface is variable and amount from a few to 80 percent. Shrubs and tree seedlings are present mainly in the clearings. Beech saplings are most common in this layer, sometimes fir saplings co-dominate (CZARNECKA 1978; IZDEBSKI et al. 1992; WILGAT 2004).

Herb layer surface is $50-90 \%$ (in most stands at least 70\%). In most natural parts of stands herb development is seasonal. Herb layer surface is largest in spring and in early summer. Herb layer does not occur in the most shaded areas of stands and is thereby characterized by high mosaicity. Moss layer is developed rather poorly. Only in some parts of beechwoods its surface is 10-40\% (IZDEBSKI et al. 1992).

Some parts of beechwoods have been changed by inappropriate forest management. The Scots Pine has been planted on deciduous forest habitat and clearcutting has been implemented. Dentario glandulosae-Fagetum occupies more than half of its potential habitat. Almost $40 \%$ of beechwood habitat is occupied by substitute associations from Querco-Fagetea class. Small share is occupied by other associations, for example Querco roboris-Pinetum fagetosum or Abietetum polonicum. In contrast, beechwood occupies almost exclusively its potential habitat. There is also a small share (ca. $0.3 \%$ ) of beechwood on Tilio-Carpinetum habitat (WILGAT 2004, Fig.1).

The Scots Pine is the main species of substitute associations of QuercoFagetea stand. Pine was planted there 50-100 years ago, and nowadays is dominant in the upper-canopy layer. In lower-canopy layer there are deciduous trees (mainly European Beech). European Beech is vivid and very often is large enough to reach upper-canopy layer. In some stands there is large share of Common Aspen (Populus 
tremula) and admixture of Silver Birch (Betula pendula) (IZDEBSKI et al. 1992). In understory layer there are Common Hazel (Corylus avellana), saplings of European Hornbeam, European Beech and Silver Fir, frequently there are also: Common Dogwood (Cornus sanguinea) or Sycamore Maple and Alder Buckthorn (Frangula alnus). Herb layer is well developed and its species composition is typical for Dentario glandulosae-Fagetum (IZDEBSKI et al. 1992).

\section{METHODS}

Potential vegetation map - scale 1:20 000 (IZDEBSKI et al. 1997) and real vegetation map - scale 1:10 000 (IZDEBSKI et al. 1991) of Roztocze National Park were compared. Additionally, tree stand maps (scale 1:20 000 for 1946, scale 1:25000 for 2001) and forest descriptions (parts of Forest Management Plan) were used to analyze species and age structure of forest stand and its changes (listed in the Appendix). Tree stand maps contained data on age and share of dominate species. Data from Forest Management Plans were more precise. Vertical structure of stand, age and species structure of all stand layers and characterisation of understory layer were included in the Forest Management Plans used in the analysis. Corel Draw and ArcView were used to draw maps and prepare statistics. Due to the lack of information about the map projection, maps were overlapped using characteristic points (roads, borders of the National Park, locations of villages, grid of forest departments).

\section{RESULTS}

\subsection{Forest stand changes}

Species composition of beechwood stand in Roztocze National Park was dominated by two tree species: European Beech and Silver Fir. As a result of natural processes and forest management proportion of fir to beech was considerably altered across the second half of 20th century. In 1946 there was mass domination of fir on $50 \%$ of the beechwood area and beech dominated on $25 \%$ of the area. In 2001 beech prevailed on $55 \%$ of the area, which means that the area of its mass domination has increased 2.2-fold since 1946. In 2001 fir dominated on 34\% of the area. Other 
significant change in species structure of beechwood was decrease of Scots Pine share $-7.5 \%$ in 1946 and ca. $1 \%$ in 2001 (Fig 2, Table 2). Statistic of $\chi^{2}$ test is 0.2457 for 5 degrees of freedom according to share of different tree species in beechwood stands in 1946 and 2001.

In age structure of beechwood in 1946 dominated forest stand of 60-120 years, which occupied $66 \%$ of the area. In 2001 the largest area was occupied by forest stand 90-150 years old (ca. 65\%). In 1946 tree stand younger than 90 years old occupied almost $55 \%$ of the area and in 2001 only $14 \%$. The oldest groups of tree stand (more than 120 years old) occupied 12\% of the area in 1946, but in 2001 it was almost three times larger $-33 \%$ (Fig. 3, 4, Table 3). Statistic of $\chi^{2}$ test is 0.9575 for 7 degrees of freedom according to age structure of beechwood stand in Roztocze National Park

The most significant changes were observed in the age group of 61-90 years. Share of this stand changed from 1946 to 2001 by ca. 24\%. Significant change occurred in the age groups of 91-120 and 31-60 years - share of both groups decreased by ca. 12 and 14\%, respectively. In contrast, share of the oldest groups (over 120 years) increased. Share of the stands of 121-150 years increased by $4 \%$ and those of 151-180 years by 16\%. In 2001 stands over 180 years were recorded, but their share were less than $1 \%$ (Fig. 3, 4, Table 3).

\section{DISCUSSION}

This was the first attempt of using forest description to analyze changes of beech stands in Roztocze. Beechwood in Roztocze National Park exists almost exclusively on its own habitat, but it occupies only half of the area. Substitute associations from Querco-Fagetea dominate the rest of beechwood potential habitat. Stands of substitute associations from Querco-Fagetea consist mostly of Scots Pine. In understory layer of this association there is domination of young beeches. What is more, herb layer composition is typical for Dentario glandulosae-Fagetum (WILGAT 2004). If proper forest management is implemented in future these artificially changed parts of the forest could be again classified as typical beechwoods. 
One of typical features of beechwood stand in Roztocze is an admixture of Silver Fir. There is a noticeable tendency of fir withdrawal from RNP stand, especially on the edges of beechwood range that neighbour with Abietetum polonicum circaeaetosum. In some cases beechwood expanded its range and took over habitat of the fir forest. What is more, there are only old specimens of fir in the beechwood stand and there are no representatives of younger generation. Dynamics of both associations need to be researched thoroughly. KOZŁOWSKA (2007) analysed changes in the montane beech forests in Bieszczady. Most data came from Bieszczady National Park and beech forests from the periods of 1954-1962 and 1994 were compared. In the Bieszczady beech forests Silver Fir was 35\% less frequent in 1994 than in 1954-1962, frequency of European Beech was the same in both periods.

There could be, however, another explanation for the decrease of the fir share in beechwood stands. In the forest management plans lands are divided on the basis of tree species mass domination. In some parts of the stands, mass of the single, old and large firs exceed mass of several younger beeches. During the period of over 50 years young beeches considerably increased their mass and outweighed the mass of sparsely distributed old firs. This process took place on $15 \%$ of beechwood area.

Obtained results show that beechwood stand in RNP became older over the second half of the 20th century. In 1974 Roztocze National Park was established and since then most valuable parts of Roztocze forests have been protected, which could play an important role in the process of ageing. In conclusion, the analysis of change tendencies in the forests of RNP indicate that beech forests are not endangered, as their area has increased since 1946. In contrary, Silver Fir share in beech forest decreased and the causes of the process should be investigated. Furthermore, I suggest that the substitute associations from Querco-Fagetea which exist on beech forest habitat are likely to transform into Dentario glandulosae-Fagetum. It is therefore possible that in the protected areas such as Roztocze National Park beech forest will develop in sustainable high forests. 


\section{REFERENCES}

BRZYSKI, B. 1983. Distribution and protection of the terminal localities of beech and fir in Rotocze and adjacent regions (south-east Poland). Ochr. Przyr. 26: 368-393.

BURACZYŃSKI, J. 2002. Roztocze. Środowisko przyrodnicze. Wydawnictwo Lubelskie, Lublin.

CZARnECKA, B. 1978. Characteristics of the Jarugi Forest Reserve in Central Roztocze. Ann. UMCS, Sec. C, 33, 21: 309-331. [In Polish with English summary].

Izdebski, K., CzarneckA, B., GrąDZiel, T., Lorens, B., PopiołeK, Z. 1991. Maps of forest plant communities and distribution of rare vascular plant species in the Roztocze National Park. Roztoczański Park Narodowy, Lublin. [In Polish with English summary].

Izdebski, K., Czarnecka, B., GrąDziel, T., Lorens, B., PopioŁeK, Z. 1992. Plant communities against the background of the Roztocze National Park habitat conditions. UMCS, Roztoczański Park Narodowy, Lublin. [In Polish with English summary].

IzDEBski, K., Grądziel, T., Lorens, B., PopiołeK, Z. 1997. Potencjalna roślinność naturalna Roztoczańskiego Parku Narodowego. Roztoczański Park Narodowy, Zwierzyniec.

KozŁowsKA, A. 2007. Changes in montane beech forests in Bieszczady. In: J.M. MATUSZKIEWICZ (ed.), Geobotanical identification of the development tendencies in forest associations in the regions of Poland, pp: 433-449. [In Polish with English summary].

LIS, Z. 1979. Natural limits of Fagus sylvatica and Abies alba in the Lublin area. Folia Soc. Scient. Lublin. Biol. 21: 119-128. [In Polish with English summary]. Wilgat, T. (ed.) 2004. The Roztocze National Park - nature and humans. Roztoczański Park Narodowy, Zwierzyniec. [In Polish with English summary]. 
Appendix (Maps and forest management plans)

Mapa drzewostanowa prowizorycznego urządzenia lasów Nadleśnictwa Państwowego Kosobudy, Dyrekcja Lasów Państwowych Okręgu Lubelskiego w Lublinie, według stanu na 1.01.1946r., skala 1:20000.

Mapa drzewostanowa prowizorycznego urządzenia lasu Nadleśnictwa Państwowego Zwierzyniec, Dyrekcja Lasów Państwowych Okręgu Lubelskiego w Lublinie, według stanu na 1.01.1946r., skala 1:20000.

Mapa przeglądowa faz rozwojowych drzewostanu, Roztoczański Park Narodowy, obręb ochronny Kosobudy, Województwo Lubelskie, stan na 1.01.2001r., skala 1:25000. Wykonano w Biurze Urządzania Lasu i Geodezji Leśnej Odział w Lublinie, wykonała Jolanta Smyk.

Mapa przeglądowa faz rozwojowych drzewostanu, Roztoczański Park Narodowy, obręb ochronny Zwierzyniec, Województwo Lubelskie, stan na 1.01.2001r., skala 1:25000. Wykonano w Biurze Urządzania Lasu i Geodezji Leśnej Odział w Lublinie, wykonała Jolanta Smyk.

Opis taksacyjny wraz z tabelą klas wieku, Nadleśnictwo Zwierzyniec, Dyrekcja Lasów Państwowych Okręgu Lubelskiego, stan na 1.10.1946r.

Operat ochronny ekosystemów leśnych rewizji nadzwyczajnej Roztoczańskiego Parku Narodowego, obręb Kosobudy, tom I, szczegółowe dane inwentaryzacji lasu, wg stanu na dzień 01.01.2001r.

Operat ochronny ekosystemów leśnych rewizji nadzwyczajnej Roztoczańskiego Parku Narodowego, obręb Zwierzyniec, tom II, szczegółowe dane inwentaryzacji lasu, wg stanu na dzień 01.01.2001r. 